\title{
Reframing and revising Australia's planning history and practice
}

\author{
Louise Johnson, Libby Porter and Sue Jackson
}

\begin{abstract}
:
Planning in Australia is always occurring on Indigenous lands. However, within the Australian planning canon, our institutions and practices have rarely acknowledged this reality. The lack of historical accuracy in accounts of urban planning histories, and the persistent inattention to the theory and practice of settler-colonialism, has blinded the profession to its complicity with colonial rule and effaced Aboriginal and Torres Strait Islander experiences. We present in this article a new way of thinking about the history of Australian planning that situates the discipline and practice of planning within Indigenous Australia. This reframing locates the history of planning inside the coexisting geographies and histories that encapsulate the subjugation, survival, resistance, and self-determination of Aboriginal and Torres Strait Islander peoples. To do so, we analyse the literature and distil key periodizations as represented in the standard planning canon and then contrast them with the histories and geographies of Indigenous peoples to construct a very different periodization of Australian planning history - one that places Indigenous political, social and cultural concerns at the centre of analysis. This reworked periodization, which aligns planning histories with major events in Indigenous history and policy, not only provides a more accurate account of the history of planning in Australia but also provides a framework for thinking about the possibilities of more positive and transformative future relationships between planning and Indigenous peoples in Australia.
\end{abstract}

Keywords: Indigenous; Planning history; Post-colonial, settler colonialism, land rights, Indigenous land management, native title 


\section{Introduction}

Planning in Australia is always occurring on Indigenous lands. Yet even with major changes in Australian land laws, such as native title, few regard this fact as fundamental to the history and contemporary practice of planning. Indeed, planning is rarely connected to the colonisation of Australian lands, or to the ongoing consequences and implications for Aboriginal and Torres Strait Islander peoples (1). In the context of international and local postcolonial theorising (such as Fanon 1986; Jacobs 1996; Said 1993; Spivak 1999; Wolf 2006) we present here a reframing of the history of Australian planning. This reframing occurs alongside major events in Indigenous policy and history, and within the context of Australia's particular form of settler colonialism (Porter 2010; Veracini 2010). This exercise has profound ethical and practical implications for planners.

If planners are to build more just relationships with Indigenous peoples, they must transform the story that planning tells about itself, where it has come from, the source of its foundational or influential theories, its impact and what it now does. After first outlining one widely circulated and accepted view of Australian planning history, this article will present a very different history. Instead of focusing on the work of planning schools, the influence of imported design theories and generation of metropolitan plans, this new history will connect the work of planning to distinct periods of colonisation and Indigenous dispossession (cf. Hibbard 2006). It will centre in the history of Australian planning spatial practices of mapping, naming, surveying segregation and assimilation, as well as Aboriginal and Torres Strait Islander struggles for self-determination and land rights. The details of this account will be limited by our expertise to a few cities and regions - New South Wales (NSW) and Sydney, Victoria and Melbourne as well as Darwin. A reworked planning history of these cities reveals both the complicity of planning in ongoing colonisation and the centrality of the agency and actions of Aboriginal and Torres Strait Islander peoples in Australia's planning story. It is on this basis that planning can be reframed, revised and reformed.

\section{Australia's planning history - the prevailing view}

The most accessible and widely circulated histories of Australian planning exist in a series of mainstream texts, widely used in planning schools and to inform academic debate. These include Hamnett and Freestone's The Australian Metropolis: A Planning History (2000); Gleeson and Low's Australian Urban Planning: New Challenges. New Agendas (2000); work by Gurran (2007) and books edited by Thompson (2007) and latterly Thompson and Maginn 
(2012) on Planning Australia. In constructing the story of the planning discipline, arguably the most influential and comprehensive scholar of Australian planning history is Robert Freestone, and his work offers the best starting point for any overview of its main events and trends. Freestone has presented many overviews of that history (such as Freestone 2000; 2010; 2014), but the basic timeline remains unchanged and it is one shared by many other scholars of Australia's planning history (such as Gurran 2011 and Thompson 2007). This story evidences a complacent orthodoxy, a prevailing view which constitutes the canon of notable developments, influences, key trends and individuals in the history of Australian planning that is rarely challenged (an exception is Sandercock 1975, 1998, 2004). Borrowing heavily from overseas conceptualisations of planning traditions, but also acknowledging Australian conditions, Freestone's timeline was represented diagrammatically in his 2010 book Urban Nation (2010: 9). We have modified his timeline here, shown in Table 1 below, to incorporate comparable formulations by Gleeson and Low (2000) and Gurran (20011). 


\begin{tabular}{|c|c|c|}
\hline Core period & Planning era & Major events and influential people \\
\hline $\begin{array}{l}18^{\text {th }} \text { to mid } 19^{\text {th }} \\
\text { centuries }\end{array}$ & Colonial foundations & $\begin{array}{l}\text { Founding and designs of settlements } \\
\text { Governors Macquarie and Darling } \\
\text { Establishment of systems of tenure and settlement } \\
\text { control } \\
\text { Creation of local government } \\
\text { Public health reforms } \\
\text { Self-government }\end{array}$ \\
\hline $\begin{array}{l}\text { 1850-early } \\
1900 \text { s }\end{array}$ & $\begin{array}{l}\text { Emergence of urban } \\
\text { reform }\end{array}$ & $\begin{array}{l}\text { Rural settlement } \\
\text { City improvement and new urban institutions } \\
1901 \text { Melbourne planning congress } \\
\text { Problems of uncoordinated growth without public } \\
\text { infrastructure } \\
\text { City Beautiful } \\
\text { Federal capital project } \\
\text { J. Sulman and W.B Griffin }\end{array}$ \\
\hline $1910 \mathrm{~s}$ & $\begin{array}{l}\text { Organised planning } \\
\text { movement } \\
\text { Legislative phase } \\
\text { begins }\end{array}$ & $\begin{array}{l}\text { Garden towns and cities } \\
\text { Planned suburbs } \\
\text { Town planning associations } \\
\text { National planning conferences } \\
\text { CC Reade, G and F Taylor }\end{array}$ \\
\hline 1920s-30s & $\begin{array}{l}\text { Experimentation, } \\
\text { institutionalisation } \\
\text { and legislation }\end{array}$ & $\begin{array}{l}\text { Melbourne and Perth Town Planning } \\
\text { Commissions } \\
\text { Town planning legislation in SA and WA } \\
\text { Comprehensive town planning and urban } \\
\text { regulation begins }\end{array}$ \\
\hline $1940 \mathrm{~s}$ & $\begin{array}{l}\text { Post-war } \\
\text { reconstruction } \\
\text { Implementation } \\
\text { begins }\end{array}$ & $\begin{array}{l}\text { Establishment of statutory planning systems - } \\
\text { Regional planning and zoning } \\
\text { Commonwealth Housing Commission and State } \\
\text { housing authorities } \\
\text { D. Winston, O. Barnett }\end{array}$ \\
\hline $1950 s-60 s$ & Long boom & $\begin{array}{l}\text { Town and country planning - Mark } 1 \text { and } 2 \\
\text { Metropolitan Master Plans, Canberra's Y Plan } \\
\text { Professionalisation of planning } \\
\text { From green belt to transport-land use corridor } \\
\text { cities } \\
\text { G. Stephenson, R. Boyd }\end{array}$ \\
\hline $1970 \mathrm{~s}$ & Rethinking planning & $\begin{array}{l}\text { Green bans and resident action groups } \\
\text { Academic critiques } \\
\text { Environmental and heritage concerns enter } \\
\text { planning legislation } \\
\text { H. Stretton }\end{array}$ \\
\hline 1970s-80s & National urban policy & Department of Urban and Regional Development \\
\hline
\end{tabular}




\begin{tabular}{|c|c|c|}
\hline & $\begin{array}{l}\text { Social Democratic } \\
\text { Managerialism }\end{array}$ & $\begin{array}{l}\text { Growth Centres and decentralisation } \\
\text { From intervention to facilitation } \\
\text { Intergovernmental co-operation } \\
\text { P Troy }\end{array}$ \\
\hline $1980 \mathrm{~s}$ & $\begin{array}{l}\text { Towards new } \\
\text { paradigms - } \\
\text { Marxism, Feminism, } \\
\text { Environmentalism }\end{array}$ & $\begin{array}{l}\text { New environmental planning legislation and } \\
\text { institutional arrangements } \\
\text { Urban management- Strategic city plans } \\
\text { Public participation } \\
\text { D Yencken }\end{array}$ \\
\hline $\begin{array}{l}\text { Late 1980s- } \\
1990 \mathrm{~s}\end{array}$ & $\begin{array}{l}\text { Competitive vs } \\
\text { sustainable cities } \\
\text { Neo-liberalism }\end{array}$ & $\begin{array}{l}\text { Building Better Cities } \\
\text { Compact cities } \\
\text { Deregulation, privatisation and planning system } \\
\text { reform } \\
\text { Environmental sustainability } \\
\text { Entrepreneurialism } \\
\text { Revival of strategic planning } \\
\text { Waterfront renewal and urban design } \\
\text { Cultural planning }\end{array}$ \\
\hline $2000 \mathrm{~s}$ & $\begin{array}{l}\text { Globalisation vs } \\
\text { quality of life }\end{array}$ & $\begin{array}{l}\text { Public-private partnerships } \\
\text { User-pays infrastructure } \\
\text { Brownfields urban renewal } \\
\text { New metropolitan strategies - Global cities } \\
\text { Master Planned Estates } \\
\text { Triple bottom line sustainability } \\
\text { Healthy cities and liveability }\end{array}$ \\
\hline
\end{tabular}

Table 1 The prevailing chronology of Australian planning (After Freestone 2010; Gleeson and Low 2000; Gurran 2007). 
In this timeline, Freestone and others acknowledge the importance of the colonial period as the "foundation" upon which the system of settlements was then built. When key events and people are noted, the colonial cities and towns become the focus of attention, with little if any mention of the land usurpation process, the regulation and subjugation of Indigenous people, contests over rights to land and other resources, or ongoing assertions of connection to country, rights to govern and manage country and demands to determine community futures. In short, this timeline is profoundly limited and historically inaccurate in its reluctance to connect these periods in Australian planning history to Indigenous people's concerns, experiences and political campaigns.

This timeline of Australian planning echoes that of the United Kingdom and the United States: with the sanitary reformers of the British industrial city giving way to the City Beautiful ideals of early $20^{\text {th }}$ century Chicago, then the Garden City notions of Ebenezer Howard and the European Arts and Craft movement in the 1920s and 30s. Such ideals were registered in decorative additions to Sydney and Melbourne, in the design of Canberra and in the garden suburbs of Sydney, Melbourne and Adelaide. The move towards comprehensive urban planning - an apparent historical and planning ideal Freestone shares with many other writers (such as Gleeson and Low 2000) - is cut short by the 1930s Depression and the two world wars, but it resumes its inexorable march in the post-war reconstruction period of the 1950s. It is at this point that real metropolitan scale planning begins, with the Country of Cumberland Plan of 1949 for Sydney and the 1953 Melbourne Metropolitan Board of Works Plan (see Alexander 2000; Howe 2000 and Hutchings 2000 in Hamnett and Freestone 2000 and Winston 1957). Here, and in subsequent discussions in the core planning history texts, the focus is on the plans themselves and on how planners attempted to meet the challenges presented by population growth, suburbanisation and the coming of mass car ownership (see Morrison 2000 and Lennon 2000 in Hamnett and Freestone 2000 and most recently Hamnett and Freestone 2017). Australian planning in the 1950s and 60s is preoccupied with administratively managing demographic, economic and technological change.

From the 1970s planning is increasingly regarded, appraised and ultimately challenged on the basis of its ideological underpinnings. It is from this point that Indigenous issues are gradually admitted into the scope of planning concerns and to its texts. Previously they had been all but absent or their presence was profoundly marginal to planners, practitioners and scholars alike. From the 1980s Indigenous peoples appear in planning histories as a brief historical cameo - as a presence prior to colonisation - before the main story of settlement 
and planning resumes; or as marginalised groups, contained within theoretical frames of "difference", or at the edge of the city or its various social and economic centres, all by forces that somehow lie outside of planning.

However, what if the experiences of Indigenous Australian's at the hands of those who surveyed, regulated and appropriated their land was put at the centre of Australia's planning story? These actors and their spatial practices preceded the formation of planning as a profession. We argue that planning on the Australian continent emerged from the earliest activities of settlers, colonial governments and other agents in the land management practices of exploring, surveying, mapping and regulating land uses along with the location of people, housing and industry. What would such a postcolonial reframing tell us about the nature of planning as a past practice - as a regulatory activity which was deeply complicit in the colonial project - but also as a discourse, the history of which needs to be recast in the light of that complicity? And what would such a re-positioning suggest in terms of future planning practices and pedagogy? Reconsidering the history of Australian planning along these lines demands a considerable conceptual reframing that will admit as central settler colonialism as an enduring structure of Australia's polity and society.

\section{Planning and the structure of settler-colonialism}

A settler-colony is a unique kind of colony. Settlers come to stay (Wolfe 1999) arriving with intentions, institutions of private property, livestock, diseases and guns. Settlers are migrants, but of a very particular kind, for they do not insert themselves into an existing order, but specifically usurp and replace that existing order with one of their own making. Differently from other kinds of colonialisms, such as those predicated on labour exploitation in plantations, the colonizing effort of settler colonialism happens within the colonised space, not from a distant metropole that remains distinct from it. In this sense, settler-colonialism is intensely productive, because it must endlessly seek to create new ways of asserting belonging and home. In staying, settler-colonialism is operationalized through a twin dynamic of institutionalizing settler privilege and replacing existing social orders. The logic then, as Patrick Wolfe has so eloquently, and terrifyingly defined, is one of elimination (Wolfe 2006). There is then a perpetual dynamic of settler-colonialism - the will to eliminate Indigenous orders. However, it is also true that this dynamic is never realised, largely due to the extraordinary struggle of Indigenous peoples, every day, in the face of that structure. 
Settlers settle through dispossession, and this happens through a twin process. First is the theft and settlement of land, and the second concerns the attempted removal of the original population through, use of force, control of resources and use of reserves and 'missions' as points of incarceration. These are the underlying foundations of Australian cities and towns, all urban settlements and processes. In this regard, settler-colonialism and its dispossessing intent and logic is a structure, not an event as Patrick Wolfe has described (2006). That structure is a specific type of violence toward and on Indigenous places and people and it is in part through the built form that this structure is imposed and maintained over time. Such a view offers a profoundly different lens through which we might consider the story of Australian planning, both in historical and contemporary terms.

\section{Re-framing Australian planning history}

There are certain points at which the accepted planning history intersects with that experienced by Indigenous Australians; with themes such as "Colonial Foundations", "Sanitarianism" and "Rethinking Planning" being critical moments. The first stage in rethinking this history, then, is to admit the Aboriginal and Torres Strait Islander encounters with the major planning developments. But to adequately render an alternative postcolonial planning history there is far more to be added to each of these periods but also other eras defined by governments as they sought to regulate most aspects of Indigenous life and by the efforts of Aboriginal people to respond, counter and re-shape state-directed administrations. In addition, there is a marked spatial and historical variability across the continent which must be acknowledged as the experience of south eastern Australia differed from that of the tropical north, though primarily in terms of timing rather than form. The account which follows draws heavily from the recent book by the authors: Planning in Indigenous Australia: From Imperial Foundations to Postcolonial Futures (2018) which exposes in far more detail the ways in which planning impacted and shaped the lives of Aboriginal peoples, with a particular focus on New South Wales, Victoria and the Northern Territory.

Stage one reframing - admitting the Aboriginal experience to the existing history

Planning for settlement began at the first moments of colonisation. Thus, in the service first of empire and then later, nation, officials produced colonial space by deploying practices, strategies and technologies that involved a physical and conceptual transformation of the land and 
regulation of social relations (Jackson, Porter and Johnson 2018; Porter 2010). Aboriginal people were initially rendered invisible - in the infamous legal fiction of terra nullius - and then classified, divided, segregated, and displaced according to the respective era's prevailing racial theories and spatial regimes (Jacobs 1996). It was from these spatializing discourses that protectorates, reserves and missions were derived and enacted across the continent. Appropriating land, defined as empty and inappropriately used, exercising power in the choice of land use, determining what uses were compatible (or incompatible and irreconcilable) and authorizing subscribed social relations with those spaces were foundational acts in the establishment of a nascent Australian planning system (Jackson 1998a). So too was the creation of a land allocation and ownership regime. The foundations of our planning system are fundamentally colonial.

In the authorised history profiled above, this era of "Colonial Foundation" is usually given scant and uncritical attention. Real planning emerges in the early $20^{\text {th }}$ century within the era of Urban Reform, with changes in health, hygiene and sanitation, which were designed to shape ambitious schemes to deliver water and remove waste, as well as regulate building forms in the burgeoning metropolitan centres. This concern with health was loudly voiced by white residents of Australian towns and cities who agitated for the removal of Aboriginal reserves beyond town boundaries, demarcating the civilised and uncivilised spaces of the nation (Jackson 1998b).

If this Sanitarian impulse remains a fundamental aim of $20^{\text {th }}$ century urban planning, the planner also ensured handsome civic spaces, well serviced suburbs and central city commerce through Organised Planning. Such aims are joined later in the $20^{\text {th }}$ century by statutory planning systems and zonings in the first metropolitan plans. This Modern planning is equated with growing professionalism, plan making and centralised expertise. In the PostWar Reconstruction era this expertise was directed at poverty and its physical manifestation in inner city slums. The 1940s and 50s therefore saw not only the first city-wide plans but the creation of State Housing Commissions which acted to destroy inner urban slums and decant their residents to other parts of the city. For Aboriginal people, the underlying physical determinism of such a view led Housing Commissions to provide "transitional housing" in the western suburbs of Melbourne and Sydney, basically sub-standard housing commission homes as a bridge from racialized slum to suburb (Broome 2005; Morgan 2006). 
By the 1970s confidence in the expert planner was shaken by the popular rejection of freeways and demands from the young, from women and from "minorities" to be heard and acknowledged in the planning system. As we have seen, Aboriginal people had been absent from the planning history before this era, even though they had always been impacted by official actions and subjected to an array of related authorities, policies and actions to regulate their lives and spaces. But in the 1970s the standard history of Australian planning explicitly intersects with Aboriginal and Torres Strait Islander peoples as the battles for land rights and heritage recognition forced changes to planning's legislative foundations. There is indeed a Rethinking of planning as notions of social difference and marginalisation come to the fore in critical planning theory. However, as Table 1 indicates, if the 1970s are typified by Green Bans and a growing environmental and social consciousness, the governmental and planning response was Social Democratic Managerialism and metropolitan strategic planning. Thus at a time when the fundamentals of the land tenure systems were being challenged, with renewed Aboriginal activism for land rights and cultural heritage legislation, the major shifts in Australia's planning history were related to neo-liberalism and moves towards deregulation, privatisation and master planning. It is therefore appropriate to not only recognise that this standard history fundamentally ignores the Aboriginal and Torres Strait Islander experience, but abrogates the planner's role in ongoing colonising actions and in restorative justice. It is therefore necessary to more comprehensively revisit and rework this timeline, to create a new history of Australian planning, beginning once again with its critical colonial foundations. It is no longer about drawing points of intersection in the existing history of planning, but rethinking its very foundations, eras and categories.

\section{$\underline{\text { Stage two reframing - towards a postcolonial history of Australian planning }}$}

The rationales and processes by which the continent was first occupied were focused initially around Sydney in the 1780s - and the various measures by which the Aboriginal occupants were removed - physically through military action and by disease, but symbolically through mapping and naming. Settler colonialism had to be enacted. Such actions left a tabula rasa on which the earliest plans could be laid out for New Albion and then the Sydney encampment. From such a point, however, lands had to be secured and this occurred through a number of planning mechanisms: by land grants, through surveys and finally, from 1831 land sale and leases which, by the 1860s were also connected to the Torrens Title system to ensure the recognition of ownership and efficacy of the associated land market. 
The attendant processes whereby lands were claimed, occupied, surveyed, mapped, named and sold occurred much later in the north of Australia with Palmerston's lands (renamed Darwin) first sold before survey in the early 1860s. Here, as with the township of Melbourne but also Adelaide, the rectangular grid layout was not only indicative of assumptions about nature and order but a precursor to a vigorous, speculative land market. Such town plans fundamentally ignored prior Aboriginal camp sites, systems of place names and other territorial relationships. The creation of the regulated land tenure system was also associated with a form of tenurial determinism, so that agricultural and sedentary forms of occupancy were constructed as superior and entitled to greater security than others - such as hunting and gathering or semi-permanent forms of land occupancy - through a series of colonial Parliamentary Acts. Before the reality of extensive pastoral activity across New South Wales and Victoria (but also Queensland), official efforts to restrict the spread of settlers beyond Sydney - in the form of the Limits of Location in the 1826-42 - gave way to legislative changes to legitimate squatting and leaseholds. The seizure of lands as part of settler colonialism had to be legalised.

While the land tenure and planning systems of the colonies were being established over the course of the early $19^{\text {th }}$ century, enacting the processes of Possession and Dispossession, Aboriginal populations were being firstly contained in settlements - on missions, reserves, compounds, schools and Native Institutions within Melbourne, Sydney and Darwin - but then physically removed to rural areas. During an early era that can be called Protection and Containment, in New South Wales, the Aboriginal populations were regulated in the Port Phillip Protectorate and later on mission, ration and reserve stations. In Darwin, the Indigenous population was confined to coastal encampments and compounds while also being effectively banned from being present in the city. The aim was both to ensure the ready, peaceful and low cost availability of lands for settlers but also to instil in the Aboriginal population a Christian, yeoman ideal on lands well removed from the burgeoning cities.

Beginning in the early $19^{\text {th }}$ century in southern Australia, the focus of authorities on confining and "civilising" Aboriginal children within city mission schools shifted to more rural reserves. By the early $20^{\text {th }}$ century, such practices were linked to an official policy of Separation, whereby the seizure and institutionalisation of Aboriginal children was legalised along with the regulation of Aboriginal location - on and off the rural reserves - on the basis of "blood" or racialized systems of classification and administered by Aboriginal "Protection 
Boards" (Broome 2005; Goodall 1996). The location and regulation of these reserves intersects with the more conventional history of Australian planning, for their presence on the edges of urban areas was related to fears for the health and hygiene of the white populations. Thus Aboriginal populations within the city and in near city reserves were associated with disease, immorality, dirt, danger and poor health. However, such conditions were created through the neglect and assumptions of the Protection Boards, or other local authorities such as missions, which, as quasi planning organisations with the power and responsibility to deliver services, were riddled with racialized assumptions about the lesser service standards needed by their charges. These near-city reserves, like those in the rural areas of NSW and Victoria, were subject to ongoing pressures for their regular removal, as the cities and towns expanded and their sanitary conditions worsened. Thus the Coranderrk Reserve near Melbourne was eventually closed in 1924, La Perouse in southern Sydney was subjected to sell offs and many attempts to relocate it, while the Kahlin Compound in Darwin was closed and its population relocated to the more remote Bagot Reserve in the 1950s. In these ways Aboriginal people were removed from any legitimate presence in the major cities while their standards of living were actually lowered through the provision of poor services and inaccessibility to centres of employment. The delineation of town boundaries was also a popular strategy of control of Aboriginal people in Australian country towns and cities like Brisbane, Darwin, Perth and Broome for many decades of the $20^{\text {th }}$ century.

While the removal of Aboriginal people and their interests from urban Australia was never total, increased in-migration to cities after World War II presented challenges to a newly professionalised planning system. As Aboriginal peoples clustered in the inner city areas of Sydney and Melbourne in search of paid work, cheap housing and extended kin networks, what was defined as the problem of slum areas generated a physical determinist solution. In association with the Assimilation policy (Markus 1994; Broome 2001), reserves were closed and dismantled while State Housing Commissions once more removed Aboriginal people from the urban cores of Sydney and Melbourne and scattered them in a "salt and pepper" pattern across their western suburban housing estates. Thus a new planning approach to Aboriginal public housing was utilised to spatially relocate and regulate Aboriginal people into suburban areas, whilst insisting on the renunciation of their Aboriginal identities and family formations. There is likely to be many other ways in which the modernising impulse impacted Aboriginal people during this era but they are yet to be recovered and represented in our formal planning histories. The account here is but a first cut at such a reframing. 
Assimilation policies in urban Australia occurred alongside a growing political movement challenging this and other oppressive and discriminatory practices. Aboriginal people had continuously questioned the various planning technologies to which they were subjected, through violent frontier resistance to the occupation of their lands, by removing their children from missions, petitioning for reserve lands, but also challenging the rule of reserve administrators and ultimately organising campaigns to secure their own lands, retrieve stolen children and improve service provision and access (Barwick 1998; Goodall 1996; Reynolds 1992).

Most recently, such campaigns have demanded Autonomy, Self-determination and land restitution as well as Recognition. One of the critical but neglected elements of the "Rethinking of Planning" that has occurred since the 1970s then were Indigenous challenges to the land tenure and cultural value systems on which planning was built. These have resulted in fundamental changes in Australian law that must have a significant impact on how the practice and philosophy of planning in Australia is conceived. The Australian High Court's decision in Mabo No. 2 and the subsequent Federal and State legislative regimes to operationalise the concept of 'native title' represent a substantive new legal framework through which planning in Australia must now be considered. Native title outcomes, while contested, limited and problematic in many ways (Dodson 1996; Smith and Morphy 2007; Watson 2005), now demand a recognition that there are substantive other layers of tenure and governance to any planning intervention than were hitherto understood and acknowledged. The notion that western planning approaches and the Indigenous planning approaches of distinct sovereign first peoples co-exist is a concept with which planning in Australia is yet to fully grasp (Jackson 1998b; Wensing 2014; Wensing and Porter 2016).

The resulting native title and cultural heritage regimes have formed the foundation of a series of planning initiatives effected by Aboriginal people across the country. These might be considered different elements of a tradition being acknowledged globally as 'Indigenous planning' (see Walker, Jojola and Natcher 2013), which can be defined as a form of planning “grounded in specific Indigenous peoples' experiences linked to specific places, lands and resources" (Matunga 2013, p.5). Indigenous-led planning initiatives reveal the variety of ways that contemporary Indigenous communities are pursuing their aspirations as distinct sovereignties, and different methods of using the planning system to achieve those aspirations (Hibbard 2006). Examples include the methods by which Indigenous people have become joint managers of protected areas, (see Jaireth and Smyth 2003; Stevens 1997; and Bauman, 
Hayes and Lauder 2013), the planning work undertaken by the Yawuru people in and around Broome (see Jackson, Johnson and Porter 2018, p.221-223), and the intersection between planning and First Peoples in Canada and Australia as documented in Porter and Barry (2016).

At the same time, national debates about the meaningful recognition of Indigenous sovereignties, and the ways in which those sovereignties might be fully operationalised in the Australian legal and political system continue. The campaign for Constitutional recognition has rekindled longstanding divisions and unfinished business particularly around Treaties, to the extent that State Governments in both Victoria and South Australia are, at the time of writing, in advanced discussions with Aboriginal people in those states towards defining a process towards Treaties. The 2017 Uluru Statement from the Heart issued by the Aboriginal and Torres Strait Islander delegates of the 2017 National Constitutional Convention called for both constitutional reforms in name of their sovereignties and a distinct voice to Parliament towards a Makarrata or coming together after struggle (see Referendum Council 2017). That the Australian Government refused to endorse the Statement is an indication of just how much unfinished business exists in the contemporary structure of Australian settlercolonialism.

It is in these contexts, then, that a new planning chronology can be distilled from this critical account of efforts to spatially remove, control, and regulate Indigenous people and their responses. This broad overview is presented below, contrasting the two time lines and their racialized eras (Table 2). 


\begin{tabular}{|c|c|c|}
\hline Period/Dates & $\begin{array}{l}\text { Planning Australia - the } \\
\text { canon }\end{array}$ & $\begin{array}{l}\text { History of Planning in Indigenous } \\
\text { Australia: Alternative timeline }\end{array}$ \\
\hline 1788-1849 & $\begin{array}{l}\text { Colonial Foundations: } \\
\text { Discovery } \\
\text { First city plans }\end{array}$ & $\begin{array}{l}\text { Possession and dispossession: } \\
\text { Mapping, naming, surveying, titling. } \\
\text { Settlement, frontier resistance, fragile } \\
\text { urban co-existence and living on country }\end{array}$ \\
\hline $1850-1900$ & $\begin{array}{l}\text { Urban reform: } \\
\text { Sanitation and water supply, } \\
\text { building and fire regulations }\end{array}$ & $\begin{array}{l}\text { "Protection" and containment. } \\
\text { Aboriginal people confined to reserves, } \\
\text { compounds, missions and fringe camps }\end{array}$ \\
\hline 1900-1940s & $\begin{array}{l}\text { Formalisation of planning: } \\
\text { Nation building, City } \\
\text { Beautiful, first planning } \\
\text { courses and first city plans }\end{array}$ & $\begin{array}{l}\text { Separation and biological management } \\
\text { via } \\
\text { reserve rationalisation, town boundaries, } \\
\text { zoning and location by "blood". } \\
\text { Aboriginal activism for national } \\
\text { inclusion. }\end{array}$ \\
\hline $1945-69$ & $\begin{array}{l}\text { Post-war reconstruction, } \\
\text { suburban expansion and first } \\
\text { metropolitan planning schemes }\end{array}$ & $\begin{array}{l}\text { Assimilation: } \\
\text { rendering invisible - via spatial policies } \\
\text { to ensure the transition to settled life, } \\
\text { racial curfews, "salt and pepper" social } \\
\text { housing. Aboriginal activism for civil } \\
\text { rights }\end{array}$ \\
\hline 1970s-80s & $\begin{array}{l}\text { Rethinking planning: } \\
\text { Environmentalism, feminism, } \\
\text { social movements, green bans }\end{array}$ & $\begin{array}{l}\text { Indigenous autonomy: } \\
\text { Land rights cultural heritage legislation, } \\
\text { dedicated services, outlawing of racial } \\
\text { discrimination. Aboriginal nationalism } \\
\text { and internationalism }\end{array}$ \\
\hline $1980 \mathrm{~s}-$ to now & $\begin{array}{l}\text { Neo-liberal planning: } \\
\text { Privatisation, public-private } \\
\text { partnerships, sustainability. }\end{array}$ & $\begin{array}{l}\text { Self-determination, Recognition: Native } \\
\text { title, urban visibility and new models of } \\
\text { Indigenous planning and land } \\
\text { management, renewed demands for } \\
\text { political settlement or treaty }\end{array}$ \\
\hline
\end{tabular}

Table 2 A new planning history of settler and Indigenous Australia 


\section{Implications for planning theory and practice}

Acknowledging the specifics of Australia's place in the British imperial system as a settler colony necessarily means a focus on just how Indigenous people were dispossessed of their lands and physically removed from it and later urban settlements. Following Wolfe (2006), our research on Sydney, Melbourne and Darwin shows in detail that this process was not a one off but an ongoing one, settler colonialism was indeed a process. In establishing the mechanisms by which such dispossession occurred - through surveying, mapping and regulating lands but also through various means of spatial confinement - we have shown how the nascent planning system of the continent was deeply complicit in the colonial project. However, we have also illustrated how such actions continued within different regulatory regimes of "separation" and "assimilation" producing new technologies of spatial power to confine Aboriginal peoples to particular places beyond or in parts of cities and towns in substandard housing and living conditions. Such a history also has to admit the ongoing resistance to such practices and acknowledge the fundamental changes to the planning system now introduced through native title and heritage regimes. But as Indigenous scholars such as Behrendt (2006, 2008, 2012) and Matunga (2013) suggest, and others within the planning profession advocate (Wensing 2012 and 2014; Porter et al 2017), there is far more to be done and planners can but also must change the ways in which they engage meaningfully with Indigenous peoples. Planning has to be about decolonising its past practices, looking critically at assumptions and material effects and working collaboratively with Aboriginal and Torres Strait Islander peoples to achieve their goals.

\section{Conclusion}

Planning is a set of practices and a discipline; and it is the latter that has been the main focus of key texts on Australian planning. An examination of these texts reveals a consensus on what planning is - a set of officially sanctioned interventions to manage land use and to deliver social and physical services. The history of such activity has tended to focus on practices enacted by those labelled "planners", and therefore only those working within governments from the 1920s. In this orthodox history, earlier interventions by governors, engineers, government officials, explorers and surveyors are rendered outside the planning system, as foundational but nevertheless marginal to the main story of planning. 
While Indigenous people are virtually never considered in planning texts before 1970 except as the invisible underpinning of the Enlightenment colonial project, the story planning subsequently tells itself effaces Aboriginal experiences. When they are admitted, it is as part of a historical backdrop, as a marginal social group or as part of a city of multicultural difference. Most recently though, Indigenous issues have assumed a presence, as a consequence of urban activism and path breaking native title and heritage court rulings. But as Jackson (1997, 1998a; 1998b), Porter (2010) and Wensing (2012; 2014; Wensing and Porter 2016) amongst others have noted, the technologies of planning - land tenure systems, mapping, zoning and regulating space in other ways - all involve interventions which directly impact on Indigenous people. In short planning has and continues to shape Indigenous Australia and the structure of settler colonialism have shaped the profession and its practice. When Indigenous peoples experiences of spatial regulatory regimes is admitted there has to be an acknowledgement that planners and their predecessors - surveyors, explorers, map makers, engineers, reserve managers - were deeply complicit in the settler colonial project (Hibbard 2016). Further, with the advent of formal planning, the processes of marginalising, removing and containing Aboriginal people within and beyond cities and towns continued, assisted by regimes of zoning, public housing administration, slum clearance and service provision. However, the story is not solely of ongoing colonisation but also of active resistance and potential transformation of the planning system through new regimes which grant rights to land, recognise native title and protect Indigenous cultural heritage. Admitting Aboriginal and Torres Strait Islander concerns, voices and experiences thus transforms the history of Australian planning but also invites further changes in the planning system. This goes well beyond processes of consultation to include genuine collaborations. In addition, some of the more profound implications of seriously admitting Indigenous concerns and ways of being into planning relate to the complex nature of Aboriginal identities, the role of extended community, and mobility in Aboriginal place-making, all of which direct planner's preoccupations away from a fixed notion of individual identity and settled, immobile, historically continuous things and spaces. There is thus a great deal more to do to not only rework and revise the history but also the practice of Australian planning before the legitimate claims of Indigenous peoples are more justly admitted. 
Note

1. We use the terms Indigenous and Aboriginal and Torres Strait Islander interchangeably in this article to refer to all who identify historically and today as first nations people in Australia.

Acknowledgements: The research for this paper was undertaken as part of the paid work Johnson and Porter do within their respective Universities. Sue Jackson was supported by the Australian Research Council's Future Fellowship Program funding scheme (project number FT130101145). Libby Porter was supported by a Vice Chancellor's Senior Research Fellowship at RMIT University. No additional funds were sought or received for this work. 


\section{References}

Alexander, I. (2000) "The post-war city" in Hamnett, S. and Freestone, R. (eds.) The Australian Metropolis: A Planning History Crows Nest: Allen and Unwin: 98-112.

Barwick, D. (1998) Rebellion at Coranderrk Canberra: Aboriginal History.

Bauman, L. Haynes, C. and Lauder, G. (2013). Pathway to co-management of protected areas and native title in Australia, AIATSIS Research Publications, Canberra.

Behrendt, L. (2006.)What Lies Beneath. In Meanjin 65(1):4-12.

Behrendt, L. (2008) Resolving Aboriginal Disputes: Land Conflict and Beyond Leichhardt: Federation Press.

Behrendt, L. (2012) Indigenous Australia for Dummies Richmond: John Wiley and Sons......

Birckhead, J., Lacy, T. De \& Smith, L. (1992). Aboriginal Involvement in Parks and Protected Areas, Canberra: Aboriginal Studies Press.

Broome, R. (2005) Aboriginal Victorians: A history since 1800 Sydney: Allen and Unwin.

Broome, Richard (2001) Aboriginal Australians: Black Responses to White Dominance 1788-2001, 3rd edn. Crows Nest, NSW: Allen and Unwin.

Dodson, M. (1996) Power and cultural difference in native title mediation. Aboriginal Law Bulletin, 3: 8-11.

Fanon, F. (1986) Black skin: White masks London: Pluto Press.

Freestone, R. (2000) (Ed) Urban Planning in a Changing World: The Twentieth Century Experience London and New York: F\&N Spon.

Freestone, R. (2010) Urban Nation: Australia's Planning Heritage Collingwood: CSIRO Publishing.

Freestone, R. (2014) "Progress in Australian planning history: Traditions, themes and transformations”, Progress in Planning 91: 1-29.

Gleeson, B. and Low, N. (2000) Australian Urban Planning: New Challenges, New Agendas Sydney: Allen and Unwin.

Goodall, H. (1996) From invasion to embassy: Land and Aboriginal politics in New South Wales, 1770-1972 Sydney: Sydney University Press.

Gurran, N. (2011) Australian Urban Land Use Planning: Principles, Systems and Practice Sydney: Sydney University Press.

Hamnett, S. and Freestone, R. (eds.) (2000) The Australian Metropolis: A Planning History Crows Nest: Allen and Unwin

Hamnett S. and Freestone, R. (eds.) (2017) Planning Metropolitan Australia Melbourne: Taylor and Francis. 
Hibbard, M. (2006) “Tribal sovereignty, the white problem and reservation planning”, Journal of Planning History 5, pp. 87-105.

Howe, R. (2000) "A new paradigm: Planning and reconstruction in the 1940s" in Hamnett, S. and Freestone, R. (eds.) The Australian Metropolis: A Planning History Crows Nest: Allen and Unwin: 80-97.

Jackson, S. (1997) "A disturbing story: The fiction of rationality in land use planning in Aboriginal Australia", Australian Planner 34: 221-226.

Jackson, S. (1998a) "Land use planning and cultural difference" in Rose, D. and Clarke, A. (eds) Tracking knowledge in north Australian landscapes Darwin: North Australia Research Unit.

Jackson, S. (1998b) Geographies of Coexistence: Native Title, Cultural Difference and the Decolonisation of Planning in Northern Australia, Unpublished $\mathrm{PhD}$ thesis, School of Geography, Macquarie University.

Jackson, S., Porter, L. and Johnson, L.C. (2018) Planning in Indigenous Australia: From Imperial Foundations to Postcolonial Futures, New York: Routledge.

Jacobs, J. M. (1996) Edge of empire: Postcolonialism and the city Abington, UK.: Routledge.

Jaireth, H. \& Smyth, D., (2003). Innovative Governance: Indigenous Peoples, Local Communities and Protected Areas. New Delhi: Ane Books.

Lennon, M. (2000) "The revival of metropolitan planning" in Hamnett, S. and Freestone, R. (eds.) The Australian Metropolis: A Planning History. Crows Nest: Allen and Unwin: 131148.

Markus, A. (1994) Australian race relations 1788-1993 Sydney: Allen and Unwin.

Matunga, H., 2013. Theorizing Indigenous Planning. In R. Walker, T. Jojola, \& D. Natcher, eds. Reclaiming Indigenous Planning. McGill-Queen University Press: 3-32.

Morgan, G. (2006) Unsettled places: Aboriginal people and urbanisation in New South Wales Adelaide: Wakefield Press.

Morison, I. (2000) "The corridor city: Planning for growth in the 1960s", in Hamnett, S. and Freestone, R. (eds.) The Australian Metropolis: A Planning History. Crows Nest: Allen and Unwin: 113-130.

Porter, L. (2010) Unlearning the Colonial Cultures of Planning Aldershot: Ashgate.

Porter, L. \& Barry, J., (2016). Planning for coexistence: Recognizing Indigenous rights through land-use planning in Canada and Australia, London: Routledge.

Porter, L., Matunga, H., Viswanathan, L., Patrick, L., Walker, R., Sandercock, L., Moraes, D., Frantz, J., Thompson-Fawcett, M., Riddle, C. and Jojola, T (2017). 'Indigenous Planning: from Principles to Practice' in Planning Theory and Practice, 18(4), doi: 10.1080/14649357.2017.1380961 
Referendum Council (2017) Uluru Statement from the Heart, available at https://www.referendumcouncil.org.au/sites/default/files/2017-

05/Uluru_Statement_From_The_Heart_0.PDF, last accessed 7 December 2017.

Said, E. W. (1993) Culture and imperialism. New York: Alfred A. Knopf.

Sandercock, L. (1975) Property, politics and planning: A history of Australian city planning, 1880-1990. Melbourne: Melbourne University Press.

Sandercock, L. (1998) Towards Cosmopolis. Planning for multicultural cities Chichester: John Wiley and Son.

Sandercock, L. (2004) "Interface: Planning and indigenous communities", Planning Theory and Practice 18 (4), 95-97.

Smith, B.R. \& Morphy, F., 2007. The Social Effects of Native Title: Recognition, translation, coexistence, Canberra.

Spivak, G. C. (1999) A critique of postcolonial reason: Towards a history of the vanishing present. Cambridge, MA: Cambridge University Press.

Stevens, S., (ed.) (1997). Conservation Through Cultural Survival: Indigenous Peoples and Protected Areas. Washington: Island Press.

Thompson, S. (ed) (2007) Planning Australia, Melbourne: Cambridge University Press.

Thompson, S. and Maginn, P. (eds) (2012) Planning Australia, Sydney: Cambridge University Press.

Veracini, L. (2010) Settler colonialism: A theoretical overview Basingstoke, UK: Palgrave Macmillan.

Watson, I., (2005) Illusionists and Hunters: Being Aboriginal in this occupied space. Australian Feminist Law Journal, 22:15-28.

Walker, R., Jojola, T. \& Natcher, D., 2013. Reclaiming Indigenous Planning, Montreal: McGill-Queen University Press.

Wensing, E. (2012) “Aboriginal and Torres Strait Islanders" in S. Thompson and P. Maginn ( Eds) Planning Australia, Melbourne: Cambridge University Press, pp. 254-27.

Wensing, E. (2014) Aboriginal and Torres Strait Islander peoples' relationships to 'country'. Chapter 2 in Byrne, J., Sipe, N. and Dodson, J. (2014) Australian Environmental Planning: Challenges and Future Prospects. Routledge, Sydney: 9-20.

Wensing, E. and Porter, L. (2016) “Unsettling planning's paradigms: Towards a just accommodation of Indigenous rights and Australian urban planning", Australian Planner 53 (2), 91-102.

Winston, D. (1957) Sydney: The Great Experiment: The Progress of the Cumberland Country Plan Sydney: Angus and Robertson. 
Wolfe, P., (1999) Settler Colonialism and the Transformation of Anthropology: The politics and poetics of an ethnographic event, London: Cassell.

Wolfe, P., (2006) Settler colonialism and the elimination of the native. Journal of Genocide Research, 8: 387-409. 